\title{
Part-time work: Atypical? Precarious? Normal?
}

\author{
Tobias Hinterseer
}

Received: 23 May 2013/Accepted: 13 August 2013 / Published online: 20 September 2013

(C) The Author(s) 2013. This article is published with open access at Springerlink.com

\begin{abstract}
There is no consensus among scholars about whether part-time work is an alerting signal of an on-going fragmentation of the labour market and of the rise in atypical working arrangements or whether it should be defined as a normal working condition as it is already fully embedded in social and labour legislation. According to the common definition of a normal, standard working condition, part-time work should be treated as atypical work. But does that also automatically make it precarious? This article starts with an overview of developments in flexibilisation and a status-quo analysis of the part-time working arrangements in Austria as a sign of labour market flexibilisation. It continues with a contention of whether part-time work as an atypical working arrangement is automatically linked to precarious working and living conditions. Using Austria as a starting point, this article closes by approaching a crucial question for all European labour markets: What form do future part-time work arrangements need to take in order to be considered "normal" from an employee's point of view? This article concludes with the assertion that discussions on the future of part-time work should not be driven by questions of definition. Rather, it would be more productive for further research to focus on offering scope for freedom of choice and social security for part-time employees.
\end{abstract}

Keywords Part-time work · Labour market flexibility .

Austria $\cdot$ Policy pointers

\section{Introduction}

We are facing an on-going trend on the labour markets in Europe: There is a significant move towards part-time work

T. Hinterseer $(\bowtie)$

Center for Futures Studies, Salzburg University of Applied Sciences,

Urstein Süd 1, 5412 Puch/Salzburg, Austria

e-mail: tobias.hinterseer@fh-salzburg.ac.at arrangements. Nearly every forth worker in Europe is working part-time (34 h or less, [1, p. 35]). Part-time working patterns vary across the continent. In the Netherlands, for example, almost half of the workforce is employed part-time, in the eight countries Austria, Belgium, Denmark, Germany, Ireland, Norway, Sweden and the UK almost a quarter of employees work in such arrangements, while in Bulgaria this figure is only around $2 \%$. A glance at the latest European Working Conditions Survey reveals that part-time working is generally synonymous with females: In the $27 \mathrm{EU}$ countries, more than $30 \%$ of women work part-time [1].

At the same time, an erosion of the normal employment conditions with respect to standard labour ${ }^{1}$ conditions and contracts can also be observed. The change of jobs, professions and working time patterns is a clear indicator for the development of increasing flexibility on Europe's labour markets. "Working times are becoming more colourful and diverse, sometimes longer but also shorter, and certainly more flexible" [3].

There is no consensus among scholars about whether parttime work is an alerting signal of an on-going fragmentation of the labour market and of the rise in atypical working arrangements or whether it should be defined as a normal working condition as it is already fully embedded in social and labour legislation. According to the common definition of a normal, standard working condition, part-time work should be treated as atypical work. But does that also automatically make it precarious?

This article starts with an overview of developments in flexibilisation and a status-quo analysis of the part-time working arrangements in Austria as a sign of labour market flexibilisation. It continues with a contention of whether part-time work as an atypical working arrangement is

\footnotetext{
"In this context the term "standard employment relationship" (SER) is also common, see for example [2].
} 
automatically linked to precarious working and living conditions. Using Austria as a starting point, this article closes by approaching a crucial question for all European labour markets: What form do future part-time work arrangements need to take in order to be considered "normal" from an employee's point of view?

This article concludes with the assertion that discussions on the future of part-time work should not be driven by questions of definition. Rather, it would be more productive for further research to focus on offering scope for freedom of choice and social security for part-time employees.

\section{Labour market flexibility}

The increase in part-time arrangements is a sign of growing flexibility on the labour markets. One question in this context is whether flexibility in fact characterises a new development at all. Kratzer [4] asserts that flexibility in itself is nothing new, although its current forms certainly are. Following this interpretation, "conventional" normal employment in a PostFordist sense is already a type of flexible employment. ${ }^{2}$ Work, labour as well as the working environment are all dramatically changing. According to Kratzer, this is not a transformation from a stable system to a flexible one, but more "(...) a transition of flexibilisation, virtually a flexibilisation of the flexibilisation" [4, p. 3].

The Austrian labour market is characterised by a heterogenic structure of entrepreneurship [5, p. 34, p. 40] and by very liberal and flexible employment protection legislation. This had been counteracted by the high impact of the so-called "social partnership" (Sozialpartnerschaft) and its interest groups (e.g. Chamber of Labour and Austrian Trade Union) who had a strong influence on hiring policies at company level. The system specific to Austria was characterised by social partners who had the power, resources and influence to control and manage domestic economic and social policies. ${ }^{3}$

In the 1980s and 1990s, Austria faced a period of significant transformation in economic and labour-related affairs. The rising international dependency and on-going neoliberal political influence challenged the social and welfare state and also changed the structure of the Austrian labour market as well as the influence of the social partnership.

Beginning in the 1980s, Austria faced [9] a period of rising flexibility which went hand-in-hand with a reduction in social

\footnotetext{
2 This can be especially explained by overtime hours which serve as an easy-to-handle flexi-tool for employers.

${ }^{3}$ For more information about the "Social partnership" as a system of industrial relations specific to Austria see: [6-8].
}

security, and the Austrian welfare system came under increasing pressure. The ÖVP/FPÖ ${ }^{4}$ coalition at the beginning of the millennium served to enhance this development. In this context, it is important to note that the perpetual conservative orientation $^{5}$ of the Austrian welfare state with its strong connection between income and access to social services still remains, because

"path-dependencies and the complex dialectic of institutions and politics still constitute - despite certain convergences with the liberal model - a system of employment specific to Austria" [5, p. 44].

Recent reforms, which " (...) resulted in a strengthening of traditional features - the respective systems now tend to be even more employment and earning-related than before" $[9, p$. 29], show evidence of this situation.

It should be noted that only the conservative orientation of the Austrian Welfare State revealed its strength: Over the course of the financial crisis, the use of short-time working arrangements was remarkably successful. The (conservative) labour market regulation with internal flexibility measures recorded better performance than external flexibility measures, such as hire and fire [11, 12].

Nevertheless, the publications of Statistik Austria ${ }^{6}$ reveal an increase in marginally-employed workers, a greater amount of temporary and subcontracted labour and the self-employed, a rise in jobs with frequently changing start and end times, and a growth in part-time working contracts. Increasing working time flexibility reflects this tendency as well as the numerical flexibility ${ }^{7}$ in Austria: Data from the Austrian Social Insurance $^{8}$ shows that a quarter of employees change their occupation within a year ${ }^{9}[15,16]$. It is the male-dominated standard ("normal") working day which is gripped by the process of erosion [17].

This tendency towards more flexibility is also revealed by the fact that only $46 \%$ of all workers in Austria have the same working hours every day (2000: $51 \%$ ). Only about $52 \%$ have stable start and end times at work (2000: $59 \%$ ) [18]. Workers within rotating job models and within shift-working contracts

\footnotetext{
${ }^{4}$ ÖVP: Christian-Conservative Party; FPÖ: Freedom Party.

${ }^{5}$ The reform of the childcare benefit scheme carried out in January 2010 underscores this finding. The income-based variant shows significant differences from the fixed alternative of childcare benefits [10].

${ }^{6}$ Statistik Austria is an independent and non-profit federal institution under public law. It is responsible for performing scientific services in the area of federal statistics (www.statistik.at).

${ }^{7}$ Numerical flexibility describes the quantitative dimension, primarily "time". Functional flexibility represents the qualitative aspects (quality of work). A further distinction can be made between external (hire and fire policies) and internal (for example, working time reductions) flexibility. For more information see: [13, 14].

${ }^{8}$ The Main Association of Austrian Social Security Organisations (www. sozialversicherung.at).

${ }^{9}$ The high job turnover rates are most probably related to the seasonal variations on the Austria labour market.
} 
increased from $15 \%$ to $19 \%$ between 1998 and 2008 [19]. According to the European Commission, "it will come to a double-tracked development in which new forms of flexible and autonomous 'knowledge work' will coexist with repetitive and intense production systems" [20, p. 7].

The trend is obvious: Working conditions in the future will become more flexible. The task is to emphasise the positive aspects of this development for both the employers and the employees. Broadly speaking, "employers welcome work on demand" while employees favour "free time on demand" [21].

A return to common and old patterns of employment cannot be the answer to these developments: Clinging to old employment structures is akin to rejecting the reality, as is forcing the "total" flexibilisation of the labour markets. Promoting the "good" dimensions (emphasising work-life balance) of more flexible working patterns is the future challenge for labour relations. This, however, is no simple task: The European Commission is committed to the enforcement of more flexible working time arrangements by employers and companies [20]. The employee-orientated flexibilisation does not follow the rhythm of economic cycles. Other issues are also important: individual working time and work load composition, more space for personal and family-related obligations as well as for vocational training.

“(...) workers wish to have more working time flexibil-

ity, most notably those who have family obligations and

those who are interested in better compatibility between

family and career" $[20$, p. 7$]$

From a normative employee-centric point of view, workers should not be forced into flexible working arrangements. Flexibilisation must serve as an alternative which guarantees social security equal to normal, full employment.

\section{Part-time in Austria}

Using the most common classification, all working arrangements with fewer than $35 \mathrm{~h}^{10}$ of work are considered parttime. In Austria, part-timers are fully included in the social system and fully integrated under labour law regulations ${ }^{11}$ : They are socially insured in the case of accidents, disease, and unemployment and also enjoy pension benefits. They are also integrated in the severance pay system. According to data from Statistik Austria, $44 \%$ of women work part-time while only $9 \%$ of men do so [23]. The overall part-time rate in Austria is around $25 \%$. The part-time working ratio of more than $80 \%$ among woman is significant [24].

\footnotetext{
${ }^{10}$ Until 2003, Statistik Austria classified part-time work as $35 \mathrm{~h}$ or less. Since 2004, self-evaluations are used. Eurofound uses the classification of $34 \mathrm{~h}$ or less.

${ }^{11}$ The last important amendments to the Austrian Labour Law in this context were implemented in 2007 (also see Hinterseer 2011) [22].
}

Explanations for the rise in atypical working arrangements like part-time work - between 2005 and 2010, the part-time rate increased by $3 \%$ annually [25] — range from people's new demands for working and living conditions to greater economic pressure and challenges. The reasons for part-time work in Austria differ between the genders: Almost four out of ten women mention family and care issues as reasons for working part-time, while only $4 \%$ of men state the same. For them, vocational training is the most common reason for part-time work. Data from Statistik Austria shows that the lower the occupational qualification, the higher the part-time rate [24].

The hourly wage is lower than in a full-time job, and compared to other countries, many part-time jobs in Austria would fall under the classification of better paid full-time employment [5]. Other problems that arise with regard to part-time work include a lack of career advancement opportunities and lower job security [26, 27]. Part-time workers are often seen as peripheral workers and are given unfavourable working times [28].

Counting unpaid housework, parenting and fostering as work, part-time employed women work even more hours a week than fully-employed men. Women in Austria reach a weekly workload of up to $60 \mathrm{~h}[18,29]$. This could be an explanation for the results of the "Arbeitsklima Index"12 in Austria which shows that most workers do not intend to move into a full-time job [18, p. 92] [30]. However, surveys in Germany emphasise that women in particular want to have the right to move into a full-time job or work more monthly hours $[27,31]$. The fact that part-time employment is seen as a preferred arrangement under special circumstances and not as a permanent status is highlighted by the fact that $34 \%$ of parttime workers view their job as a "workaround" and almost a third of part-time workers explicitly want to work more [32].

The development in the future expansion of part-time work will mainly depend on the following factors: Investment in childcare facilities and progress towards more flexible forms of employment (flexitime, working time accounts) will lead to a decrease in employed women working part-time but will increase the overall rate of employed women at the same time. Further development is also dependent on the acceptance of part-time work in society in general: If workers in higher positions work part-time more often, this will have an influence on the overall rate. The longer life expectancy as well as the improved health conditions of the elderly, who will work more during their retirement, will also have an impact on the part-time workforce. Taking into account a simple extrapolated trend of the part-time developments and the Austria-

\footnotetext{
${ }^{12}$ The "Arbeitsklima Index" is regularly conducted by the Chamber of Labour in Austria (Arbeiterkammer) to measure the subjective well-being of workers. For further information see: http://www.arbeiterkammer.com/ gesundheit/arbeitsklima.htm.
} 
specific parameters, a part-time rate of about a third is realistic in Austria for 2020 [33]. In this context it should be noted that in the first half of 2010, a rise in part-time working arrangements was statistically related to a decrease in full-time employment while the unemployment rate declined slightly [34-36]. It is also statistically proven that the rise in employment in Austria since 1995 exclusively stems from the growth in part-time work [24].

\section{Atypical? Precarious? Normal?}

Analysing the European labour markets reveals that the rise in atypical work reflects an on-going neoliberal economic trend $[37,38]$. Data show a rapid and permanent erosion of normal working contracts. "Normal" in this context means permanent and full employment with stable starting and end times, from Monday to Friday [39, p. 3f]. Consequently, every work situation which differs from this definition is considered atypical. The increase in atypical work threatens the social system and its tax-based foundations, which relate mainly to the "normal" working classification. The adjective "precarious" is often used in connection with atypical working arrangements. Browsing the relevant scientific literature reveals the vagueness of the term. "Occasionally the borders between atypical and precarious become blurred in a synonymous equalisation" [26, p. 502]. Brehmer and Seifert [26] build some categories which help to define variables for precarious work. Working arrangements which are changed in the course of flexibilisation should be operationalised through the following dimensions: income, job security, employability and social security. The authors show that a combination, or rather the accumulation of these different dimensions, leads to precarious situations. But even with this categorisation of the problem area, defining what is precarious or not continues to be a complex issue. When it comes to subjectivity and the selfdetermination of workers to characterise precarious work, the concept becomes more vague and difficult to operationalise $[26,40]$. Atypical work like temporary agency work or nonpermanent part-time work could, for example, serve as a starting point for a stable working situation and could therefore not automatically be defined as precarious work. In other contexts, such work could also lead to instability and social troubles.

Nevertheless, for a rising number of people, this leads to precarious working and living situations, and studies show that workers in atypical work situations face a higher risk of precarious working and living conditions [40]. The great increase in part-time jobs underlines these assertions. Compared to 1998 , when $16 \%$ of all employees were part-timers, almost a quarter of the work force is currently part-time employed in Austria. Open-end contracts are still in the majority, but the number of non-permanent contracts is constantly growing [29]. As a consequence, should part-time work be included in a group with the increasing number of marginally-employed workers, the greater amount of temporary and subcontracted labour and the self-employed, who are usually categorised as atypical?

More and more scholars argue that part-time work should no longer be seen as atypical employment (for Austria, see for example [41]). ${ }^{13}$ As already stated, part-time work in Austria is socially and legally equal to full-time work. In line with this interpretation, almost $90 \%$ of the workforce in Austria is currently "normally" employed.

Work is made precarious by special forms of flexibilisation. The labour market expert Marcel Finke defines the "rise in non-standard forms of employment" [9] as one of these developments. This includes all jobs without collective agreements. The number of such forms of employment is rising, but most of the workers are still embedded in collective agreements - also part-time work arrangements. Another form is the low-wage sector of the labour market. This sign of flexibilisation and especially of deregulation in the labour market is not only a problem for part-time workers: Almost $15 \%$ of the full-time employed in Austria already work in a precarious low-wage sector. What actually leads to a risky situation for workers is the combination of atypical arrangements, like a non-permanent part-time job. It must be noted that the degree of precariousness differs between job branches: In Austria, for example, jobs in the tourism industry are affected most [42].

To sum up, above all, fictitious self-employment ("Scheinselbständigkeit”), minor working contracts, temporary agency work and non-permanent part-time work are increasingly undermining labour law and social law regulations. These forms of work indicate a high rate of involuntary employment [43]. Brehmer and Seifert [26] investigated the correlation between atypical forms of employment (non-permanent, part-time work included) and the risks of precarious work for Germany. Their results demonstrate that the atypically employed are more at risk of working in a precarious situation than workers in a "normal" form of employment. The authors also claim that

"(i)t cannot be stated at all, that all these forms of employment are precarious per se. According to the analysed characteristics, the majority of atypically employed workers cannot be classified as precariously employed. The research neither implies that all normal working arrangements are free of precarious risks" $[26$, p. 516].

\footnotetext{
$\overline{13}$ The literature on Danish flexicurity tends to assume that workers are in regular open-ended contracts, or, if not, that part-time or temporary contracts can be considered equivalent to regular employment [1, p. 18].
} 
Due to the full integration into the labour and social law regulations, holding part-time work in Austria is not a precarious situation for most employees. Generally, however, most problems arise in the future: In case of redundancy, unemployment benefits, severance pays and pension rates are lower in comparison to long-time full employment. Women in particular suffer in this context. The high part-time rate in combination with high divorce rates and the paternalistic orientation of the Austrian welfare state should be taken into account in this connection [5, 44]. Especially in Germany, against the backdrop of the Hartz IV reforms, non-standard forms of employment are criticised, as is part-time work. In statistical studies, all working contracts with $35 \mathrm{~h}$ or less are classified as part-time work. As a result, the variations of working hours are high, and differentiations between what is categorised under the term part-time work are essential.

\section{Policy pointers}

Part-time work is a persistent trend on Europe's labour markets and reflects the development of deregulation and flexibilisation. Part-time work is mostly grouped under atypical work and therefore automatically connected with precarious working and living conditions: low wages, a low level of social security and a high rate of involuntary work [43].

In labour market contexts, where these forms of employment differ significantly from the common social and legal setting, these assumptions are true. Adaptions to labour law regulations, such as in Austria, treat part-time work almost as equal to full-time work and thus challenge this connection.

Political decisions are needed to embed the increasing parttime arrangements into a modern labour market setting, in which flexibility is not only employer-driven but also flanked by reduced future risks. It is particularly difficult for political decision-makers to influence the quantitative development of atypical part-time work. On a qualitative level (social rights, labour law, wage issues), however, there is more potential for political influence in terms of "context governance" [37].

The following list constitutes an initial attempt to propose political measures which are essential to disconnect part-time work from precarious working and living conditions. These policy pointers could serve as a starting point for further discussion and promote further in-depth research. As mentioned in this article, it is difficult to define what makes work precarious. The following policy pointers are based on the categorisation of Brehmer and Seifert [26].

More employee-orientated flexibility

The common approach to work is changing. The boundaries between working time and private time are being blurred.
Work as one element of a complex life framework is more often seen as a major impact on the quality of life.

"The practice of (...) flexibilisation strategies often does not overlap with the wishes and needs of workers, because the opportunities for participation are small and there is little room for planning the daily routine" [45].

Flexible working (time) arrangements are therefore increasingly gaining in favour. This trend will continue in the near future. This especially concerns those who face the task of combining family obligations with work duties. The increasing flexibility offers new potential for people to combine work and private spheres more sufficiently. Yet, as the German Trade Union (DGB) shows, the connection between these two spheres is not always promising [46]. The vague border between work, leisure, family and privacy is a major stress factor for employees. OECD studies point out the relationship between a successful work-life balance and familyfriendly working time arrangements $[47,48]$. Positive flexible arrangements are flexitime, working time accounts, trusted flexitime, opportunities for home-working, sabbaticals and different forms of leave.

The right to change from full-time to part-time and vice versa

This innovation from the Dutch labour market system should be at the core of modern labour markets with rising part-time work arrangements in Europe. It guarantees a better basis especially for women - to combine childcare with professional plans.

Full inclusion in the social system and integration under labour law regulations

As mentioned in this article, in 2007, Austria made a big step towards the full integration of part-time work under social and labour law regulations. This should become European standard to avoid part-time marginalisation. The Netherlands has gone one step further and given these rights to marginally employed workers, too. Furthermore, the flexibilisation of working conditions and working time should always be connected with collective agreements and employee councils to reduce the risk of one-sided flexibility developments.

\section{Breaking down traditional role models}

Women - and this is a European phenomenon - dominate the part-time workforce. Therefore, it is crucial to break down traditional role models. In conservative welfare states such as Austria, women are usually associated with family and household issues while men are connected with job and career agendas. Highly-skilled workers and managers in part-time work are not socially-accepted enough and traditional family 
roles still tend to be attached to women. The still high gender pay gap reflects this issue. The Dutch case shows the potential to change this mind-set with its remarkably high part-time rate among men (23\%; Austria: $9 \%)$.

Mandatory parental leave for men between two and six months as well as extra wage increases for women ${ }^{14}$ could help to challenge not only these role models but also the gender pay gap.

\section{Expansion of childcare institutions}

Women not only frequently prefer part-time work because of the aforementioned high amount of unpaid work but also because childcare institutions are insufficient, too expensive or both in most of Europe.

On the one hand, more public funding is required for day nurseries, for affordable and local kindergartens and for allday schools. The exemplary child care system in Sweden is tax funded and has a maximum cost limit for parents to make child care affordable [50]. On the other hand, social partners and political decision makers have to encourage employers to support their employees who have children. In Germany, we see, for example, an expansion ${ }^{15}$ of on-site childcare facilities, which not only helps parents to combine work and family issues more easily but also brings advantages for employers and companies. ${ }^{16}$

Reduction in overtime, working time and non-permanent working contracts

Extra hours are an important flexibilisation tool for employers. A reduction in the high amount of overtime hours in Austria (about 350 million) [19] would have positive effects on the labour market. This working time reduction would offer a new distribution for work. New jobs could be generated and part-time workers could increase their working hours more easily. Through a higher rate of taxation, overtime hours should be made more unattractive for employers and always be counterbalanced by compensation time or payments.

Part-time employment functions, like overtime (where Austria is leading the way in Europe), as a flexi-tool for employers. A general reduction in working time, like in Sweden, the Netherlands, Belgium and France, would be sufficient and could help to create new jobs [53,54].

As mentioned above, combinations of atypical working arrangements increase the risk of precarious working and

\footnotetext{
${ }^{14}$ The Austrian Trade Union proposed such extra wage increases for women in Austria in 2011 [49].

${ }^{15}$ From 2007 to 2011, company-based childcare increased by almost $50 \%$ [51], p. 60.

${ }^{16}$ A representative survey amongst companies in Germany reveals economic advantages for companies with a family-friendly personnel policy and human resources management [52].
}

living conditions. Part-time and/or non-permanent contracted workers should have a preferential right for applying for newly advertised vacancies within the same company.

\section{Reducing the risks of future precarious conditions}

As stated earlier, for most workers in countries where parttime work is socially and legally equal to full-time employment, working part-time does not automatically lead to a precarious situation. But in the case of unemployment or retirement, part-time work reveals its risks, especially in Austria with its strong connection between income and access to social services. For this reason, long-term part-time workers should benefit from higher severance payments as well as taxes for pension funds and unemployment benefits. To guarantee this, part-time workers should receive a plus on their pay-checks up to $10 \% .{ }^{17}$ Once more the (state and strength of the) social dialogue is crucial: social partners could negotiate the actual amount of the extra payment as part of the wage rounds, depending on branches and their specific part-time distribution and renumeration. Such a step would help minimise social risks - for both voluntary and involuntary parttime workers - and reduce the flexi-advantage for employers to only hire part-time workers. Paying higher unemployment benefits for part-time workers, especially single parents, would reduce a plethora of social risks in this context, as would minimum wages. This issue should not only be discussed at a national level but, above all, on a European one.

Particularly when it comes to combined atypical working arrangements, such a bonus for special risk should be introduced. It could be paid as a lump sum on entry into the "risky" job or paid as a monthly wage add-on [40].

\section{Conclusion}

It is clear to see that part-time work is a current phenomenon of the European labour markets. It is a sign of the on-going trend towards the flexibilisation and differentiation of work. Categorised under atypical working arrangements, part-time work is often connected with precarious working and living conditions for employees. As shown in this article, under certain circumstances, this assumption can be true. The outlined trend toward more flexibility will continue, as will the struggle between employee- and employer-orientated flexibilisation.

In spite of these developments on the labour markets, conventional "normal" work remains the most common form of employment in Austria and Europe as a whole [54, 57].

Work will not dry up, but will only be distributed differently: This conflict of distribution will be one of the specific

\footnotetext{
${ }^{17}$ The additional wage rate is based on the bonus for precarious work (temporary and subcontracted labour) on the French labour market [55, 56].
} 
disagreements between labour and capital. And part-time work will be one of the major aspects of this discussion.

As Austria serves as the starting point for discussion, whether part-time work is defined as atypical work or not is not the crucial question. The social circumstances for individuals are much more important: Do I have the choice to work full-time or part-time, and if I choose the latter, am I socially protected? If the policies mentioned above are implemented, part-time work could be categorised under normal employment without any uncertainty.

In conclusion, "normal" should not refer to any relations to traditional working patterns. Instead, "normal" should be used for all working arrangements which guarantee a high amount of social security and individual freedom for employees. Flexible working time models need to adopt a more employee-friendly orientation, with more time-autonomy and self-determination being crucial to this. To achieve this goal, flexibility must be managed and controlled politically. As Rodgers (2007) points out:

"It is precisely this combination of institutions and policies which constitutes a social model. (...) While a wide variety of approaches may work in different situations, one important lesson from successful experiences in both Europe and elsewhere is the essential nature of broad participation and social dialogue in the process" $[58$, p. 8$]$.

The International Labour Organisation (ILO) defines the following five crucial dimensions for a proper working time: (i) healthy working time, (ii) family friendly working time, (iii) gender equality by working time, (iv) productive working time, and the very important dimension (v) choice and influence regarding working time [59]. For most of Europe's parttime workers, these goals are still far from being achievable.

Using the changes in the standard working conditions as a major benchmark for debate on labour market developments, researchers often " (...) speak almost exclusively of erosion and crisis rather than of change" [60, p. 41]. Therefore, the implementation of the proposed policies is the first step towards a shift to an employee-friendly modern and flexible labour market.

Open Access This article is distributed under the terms of the Creative Commons Attribution License which permits any use, distribution, and reproduction in any medium, provided the original author(s) and the source are credited.

\section{References}

1. Eurofound (2012) 5th European Working Conditions Survey. Luxembourg

2. Boulin J-Y, Lallement M, Messenger JC, Michon F (2006) Decent working time- New trends, new issues
3. Seifert H (2007) Arbeitszeit- Entwicklungen und Konflikte. Aus Polit Zeitgesch 4-5:17-24

4. Kratzer N (2002) Thesen zur Flexibilisierung des Arbeitseinsatzes.

5. Hermann C, Flecker J (2010) Das "Modell Österreich" im Wandel. In: Hermann C, Atzmüller R (eds) Die Dynamik des" österreichischen Modells": Brüche und Kontinuitäten im Beschäftigungs-und Sozialsystem. edition sigma, Berlin

6. Tálos E (2008) Sozialpartnerschaft. Ein zentraler politischer Gestaltungsfaktor in der Zweiten Republik. StudienVerlag

7. Karlhofer F, Talos E (2000) Sozialpartnerschaft unter Druck. Trends und Szenarien. In: Pelinka A, Plasser F, Meixner W (eds) Die Zukunft der österreichischen Demokratie. Trends, Prognosen und Szenarien. pp 381-402

8. Tálos E (2005) Vom Vorzeige-zum Auslaufmodell? Österreichs Sozialpartnerschaft 1945 bis 2005. Sozialpartnerschaft, Wien, S: $185-216$

9. Fink M (2006) "Flexicurity" as a Concept for Welfare State Reform? Findings from an Examination of Different Welfare State Systems: Austria, Denmark and the UK Compared

10. help.gva.at (2010) Kinderbetreuungsgeld. http://www.help.gv.at/ Content.Node/8/Seite.080601.html. Accessed 12.02.2013

11. Bock-Schappelwein, Julia Mahringer H, Rückert E (2011) Kurzarbeit in Deutschland und Österreich

12. Herzog- Stein A, Lindner F, Van Treeck T (2010) Vom Krisenherd zum Wunderwerk? Der deutsche Arbeitsmarkt im Wandel. IMK Report 56

13. Wilthagen T, Tros F (2004) The concept of 'flexicurity': a new approach to regulating employment and labour markets. Tran Eur Rev Labour Res 10(2):166-186

14. Vodruba G (2008) Flexiblität und Grundeinkommen. In: Füllsack M (ed). transricpt, Bielefeld, pp 115-131

15. Guger A (2006) Arbeitsmarktflexibilität und soziale Absicherung. WIFO-Weißbuch: Mehr Beschäftigung durch Wachstum auf Basis von Innovation und Qualifikation. WIFO, Wien

16. Mahringer H (2005) Essays on child care costs and mothers' employment rates and on trends in job stability. Linz

17. Schmid T (2000) Arbeit und ihre Zukunft. In: Reichel R, Lesnik M (eds) Ist Arbeit sozial? Arbeit neu bewerten- Ein Lesebuch. ÖGB Verlag, Wien, pp 15-48

18. Eurofound (2007) Fourth European Working Conditions Survey

19. BMASK (ed) (2010) Arbeitsbedingungen in Österreich, vol Band 4. Arbeitszeiten und Vereinbarkeit. Sozialpolitische Studienreihe, Wien

20. Europäische Kommission (2010) Überarbeitung der Arbeitszeitrichtlinie

21. Popp R, Hofbauer R, Pausch M (2010) Lebensqualität-Made in Austria: Gesellschaftliche, ökonomische und politische Rahmenbedingungen des Glücks. LIT Verlag Münster

22. Hinterseer T (2011) Flexicurity in Österreich- Sozialpartnerschaft just renamed? Hamburg Rev Soc Sci 6(2):57-76

23. Statistik Austria (2013) Teilzeit, Teilzeitquote. Arbeitsmarkt

24. Wien A (2011) Teilzeitbeschäftigung in Österreich. Sozial- und Wirtschaftsstatistik aktuell 6/2011

25. Eichmann Hea (2010) Überblick über Arbeitsbedingungen in Österreich. Sozialpolitische Studienreihe, vol Band 4

26. Brehmer W, Seifert H (2007) Sind atypische Beschäftigungsverhältnisse prekär? Eine empirische Analyse sozialer Risiken. Zeitschrift für Arbeitsmarkt Forschung 41(4)

27. IAB (2011) Viele Frauen würden gerne länger arbeiten. IAB Kurzbericht- Aktuelle Analysen aus dem Institut für Arbeitsmarktund Berufsforschung 9/2011

28. Bundesministerium für Frauen und Öffentlichen Dienst (2010) Frauenbericht 2010. Wien

29. Buschak W (2007) Arbeiten in Europa - Vergleiche - Trends Perspektiven. WISO, Wirtschafts- und sozialpolitische Zeitschrift, Institut für Sozial- und Wirtschaftswissenschaften Linz 30(3):18-32

30. Arbeiterkammer Salzburg (2011) Arbeitsklima Index 2011, unveröffentlichte Ergebnisse 
31. IAB (2004) Teilzeitarbeit. IAB Kurzbericht- Aktuelle Analysen aus dem Institut für Arbeitsmarkt- und Berufsforschung 18/20.02. 2004

32. SORA (2006) Arbeitszeitwünsche von Teilzeitbeschäftigten. SORAInstitute for Social Research and Analysis Wien

33. Belabed AC, Hinterseer T (2013) Zehn Mythen zur Zukunft der Arbeit. ÖGB Verlag, Wien

34. Statistik Austria (2009) Arbeitsmarktstatistik Jahresergebnisse 2009. Mikrozensus-Arbeitskräfteerhebung Schnellbericht

35. Statistik Austria (2010) Arbeitsmarktstatistik 1. Quartal MikrozensusArbeitskräfteerhebung Schnellbericht 5.82010

36. Statistik Austria (2010) Arbeitsmarktstatistik 2010 2. Quartal. Mikrozensus-Arbeitskräfteerhebung Schnellbericht

37. Fink M (2004) Atypische Beschäftigungsverhältnisse und deren politische Steuerung im internationalen Vergleich. Österr Z Polit Österr Ges Polit 39:401-415

38. Butterwege C, Lösch B, Ptak R (2008) Kritik des Neoliberalismus, 2nd edn. VS Verlag für Sozialwissenschaften, Wiesbaden

39. Grafl A (2012) Atypische Beschäftigungsverhältnisse-Segmentationstheoretische Erklärung und empirische Analyse der Entwicklung in Österreich. Materialien zu Wirtschaft und Gesellschaft, vol 112. Wien

40. Keller B, Seifert H (2011) Atypische Beschäftigungsverhältnisse. Stand und Lücken der aktuellen Diskussion. WSI Mitteilungen 3/2011

41. Hofbauer R (2010) Die Gute Arbeit 2020. Renner Institut Salzburg, Salzburg

42. Casali S, Alvarez Gonzalez V (2010) Population and social conditions. eurostats- Statistics in focus $3 / 2010$

43. Teitzer R (2012) Unfreiwillig befristete Beschäftigung in ÖsterreichAusmaß, Trends und Risikogruppen. Hamburg Rev Soc Sci 6/7(3/ 1):73-93

44. Riesenfelder A, Schelepa S, Wetzel P (2011) Geringfügige Beschäftigung in Österreich. L\&R Sozialforschung, Wien

45. Littig B, Leitner A, Wroblewski A (2005) Work Life Balance in Österreich- Endbericht am Institut für Höhere Studien für das österreichische Lebensministerium im Rahmen der Studie nichtnachhaltige Trends in Österreich
46. DGB (2007) Work- Life- Balance 2007- Der Report. DGB- INdex Gute Arbeit

47. OECD (2007) Babies and Bosses- Reconciling Work And Family Life- A Synthesis of Findings for OECD Countries.

48. OECD (2003) Babies and bosses- reconciling work and family life- a synthesis of findings for OECD countries. Vol 2. Austria, Ireland, Japan

49. Ettinger K (7.9.2011) Extra-Erhöhungen: Löhne für Frauen sollen stärker steigen. DiePresse.com. http://diepresse.com/home/ wirtschaft/economist/691370/ExtraErhoehungen_Loehne-fuerFrauen-sollen-staerker-steigen. Accessed 15.03.2013

50. Dörfler S (2007) Kinderbetreuungskulturen in Europa. Ein Vergleich vorschulischer Kinderbetreuung in Österreich, Deutschland, Frankreich und Schweden vol Working Paper Nr. 57 | 2007. Wien

51. Statistisches Bundesamt (2012) Statistisches Jahrbuch 2012. Deutschland und Internationales

52. Gerlach I, Schneider H, Schneider AK, Quednau A (2013) Kurzfassung-Ergebnisse der repräsentativen Unternehmensbefragung 2012 zur Vereinbarkeitvon Beruf und Familie. Münster, Berlin

53. Marterbauer M (2011) Mit Arbeitszeitverkürzung zu wünschenswerter Arbeitskräfteknappheit WISO 2/11 17-32

54. Flecker J, Schönauer A, Hermann C, Allinger B (2010) Arbeitszeitverkürzung zur Umverteilung von Arbeit - internationale Beispiele. FORBA-Forschungsbericht 1/2010

55. OECD (2013) OECD Economic Surveys FRANCE- Overview

56. Soost S (2012) Leiharbeit: Prekariat auf Abruf Blätter für deutsche und internationale Politik

57. Eurofound (2010) Changes over time - First findings from the fifth European Working Conditions Survey

58. Rodgers G (2007) Labour Market Flexibility and Decent Work. DESA Working Paper No 47

59. ILO (2007) Decent Working Time- Balancing Workers' Needs with Business Requirements

60. Bosch G (2006) Working time and the standard employment relationship. In: Boulin J-Y, Lallement M, Messenger JC, Michon F (eds) Decent working time- New trends, new issues. International Labour Organisation, Geneve, pp 41-64 